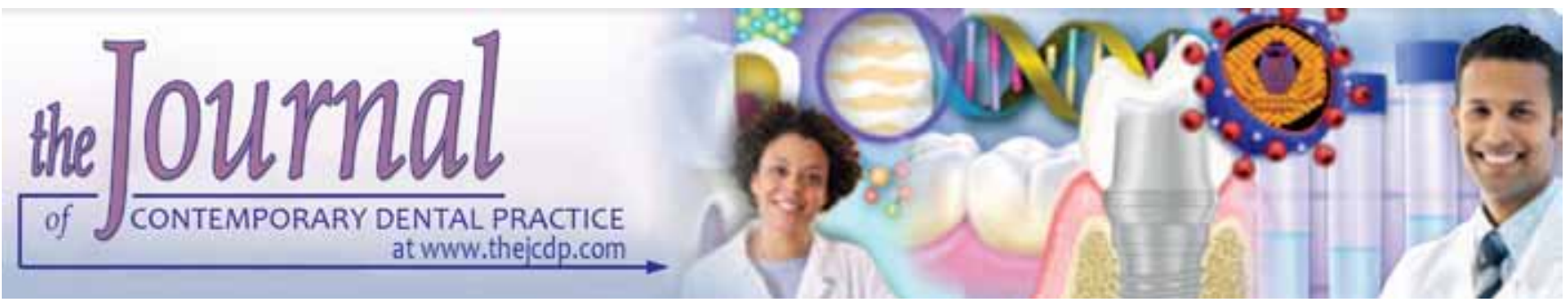

\title{
Assessment of DNA Damage in Leukoplakia Patients with Different Degrees of Dysplasia
}

\author{
${ }^{1}$ Sajith Vellappally, ${ }^{2}$ Mohammed A Binmgren, ${ }^{3}$ Sahar Bin Huraib, ${ }^{4}$ Mohamed I Hashem \\ ${ }^{5}$ Shankargouda Patil, ${ }^{6}$ Sukumaran Anil
}

\section{ABSTRACT}

Background: Single cell gel electrophoresis (SCGE) assay also known as comet assay is a rapid and highly sensitive fluorescent molecular technique for detecting various forms of deoxyribonucleic acid (DNA) damage at individual cellular level.

Materials and methods: The present study was done to detect the extent of DNA damage in oral leukoplakia $(\mathrm{OL})$ and compare with normal individuals. The sample population was obtained from an outpatient clinic of a tertiary teaching dental institute. A total of 36 consecutive patients with leukoplakia and 10 healthy normal volunteers were recruited for the study and assessed for the extent of DNA damage using SCGE following clinical diagnosis and histological grading. Peripheral blood was obtained by venipuncture and SCGE assay was performed. Mean comet tail length was recorded and analyzed statistically to compare the extent of damage in each group.

Results: The mean comet tail length seen in leukoplakia patients with moderate to severe dysplasia was $1.25 \pm 0.14 \mu \mathrm{m}$ while for the control subjects, it was $0.31 \pm 0.10 \mu \mathrm{m}$. The difference was statistically significant $(p=0.000)$. On comparing within the grades of leukoplakia, a progressive trend of increasing tail length was observed with increasing grades of dysplasia.

\footnotetext{
1,2Department of Dental Health, Dental Biomaterials Research Chair, College of Applied Medical Sciences, King Saud University, Riyadh, Saudi Arabia

${ }^{3}$ Department of Dental Health, Dental Public Health, College of Applied Medical Sciences, King Saud University, Riyadh Saudi Arabia

${ }^{4}$ Department of Dental Health, College of Applied Medical Science, King Saud University; Dental Biomaterial Department Al-Azhar University, Cairo, Egypt

${ }^{5,6}$ College of Dentistry, Jazan University, Jazan, Saudi Arabia

Corresponding Author: Sajith Vellappally, Assistant Professor Department of Dental Health, College of Applied Medical Science, King Saud University, Riyadh, Saudi Arabia, e-mail: ksucod@gmail.com
}

Conclusion: Deoxyribonucleic acid damage as measured by SCGE is seen in leukoplakia. A stepwise increase in DNA damage levels from healthy controls, through patients with non-dysplastic epithelium to varying grades of dysplasia has been observed indicating the extent of DNA damage in this high risk group.

Keywords: Biological markers, Comet assay, DNA damage, Dysplasia, Leukoplakia, Premalignant lesions, Single cell gel electrophoresis assay.

How to cite this article: Vellappally S, Binmgren MA, Huraib SB, Hashem MI, Patil S, Anil S. Assessment of DNA Damage in Leukoplakia Patients with Different Degrees of Dysplasia. J Contemp Dent Pract 2015;16(12):971-976.

\section{Source of support: Nil}

\section{Conflict of interest: None declared}

\section{INTRODUCTION}

Oral leukoplakia (OL) is the most common premalignant or 'potentially malignant' lesion of the oral mucosa. The estimated prevalence of OL worldwide is 2 to $4.9 \% .{ }^{1}$ Oral leukoplakia usually occurs after the age of 30 to 40 years with no gender predilection. Tobacco has been considered a risk factor and OL is six times more common in smokers than in non-smokers. ${ }^{2,3}$ Alcohol intake and the possible etiologic role of the human papilloma virus (HPV) in OL is not yet clear. ${ }^{4,5}$

The clinical appearance of leukoplakia is important as homogeneous lesions are reported to have a lower rate of malignant transformation than lesions which are speckled, erosive, ulcerative, or verrucous in appearance. ${ }^{6}$ Several factors have been suggested to predict an increased risk of malignant transformation of OL, such as age, gender, tobacco habits, homogeneity and size of the lesion, site of the lesion, degree of epithelial dysplasia and loss of heterozygosity., 7

The precancerous nature of leukoplakia has been established based on several factors. In various studies, 
15.6 to $39.2 \%$ of leukoplakia biopsy samples have demonstrated epithelial dysplasia or invasive carcinoma, and more than one third of oral carcinomas have areas of leukoplakia in close proximity. ${ }^{9,10}$ The hallmark for cancer progression is inheritable cellular deoxyribonucleic acid (DNA) damage as a result of the effect of carcinogenesis or due to genetic errors. When such defects are detectable and quantifiable, these values may contribute toward an easy detection and prediction system for oral cancer development and prognosis. Molecular and genetic techniques have enabled us to unravel some of the critical events in DNA damage. One such technique is the single cell gel electrophoresis (SCGE) assay, more popularly known as comet assay. ${ }^{11}$

The risk of malignant transformation of leukoplakia with dysplasia has been reported to be high as $43 \%$, hence the need for regular monitoring. ${ }^{1}$ Histological criteria are effective in judging the malignant risk of leukoplakia with severe dysplasia or carcinoma in situ, and these lesions if left untreated have a high rate of malignant transformation. Lesions without dysplasia or with minimal dysplasia pose the greatest management challenge to clinicians. Hence in such situations histological criteria alone are poor predictors for these lesions. ${ }^{12}$

Though there are several methods to evaluate oral epithelial dysplasia, there is no universal agreement in this regard. ${ }^{13-15}$ Peripheral blood ${ }^{16}$ and the serum ${ }^{17}$ have been extensively studied as oral cancer and dysplasia biomarkers, though lacking in specificity. Reports on the extent of DNA damage in patients with oral epithelial dysplasia are few. The present study was undertaken to perform and confirm the extent of DNA damage in patients with leukoplakia showing different grades of dysplastic oral epithelium.

\section{MATERIALS AND METHODS}

This study was approved by the Institutional Review Board of the College of Applied Medical Sciences, King Saud University, Riyadh, Saudi Arabia. Forty patients with histologically confirmed OL was included in the study group. A detailed medical and dental history of the patients was taken and clinical details were recorded. The patients who were not willing to participate and those on medications or suspected of suffering from any systemic illness were excluded from the study. An informed consent was obtained from all patients.

Subjects with histologically proven cases of leukoplakia were included. Based on the grade of epithelial dysplasia the groups were classified as: nondysplastic, mild to moderate and severe according to the criteria of Kramer et al. ${ }^{18}$ A control group consisting of healthy subjects were included. The healthy group consisted of individuals without any systemic illness and those free from habits, such as smoking or chewing tobacco.

\section{Collection of Samples}

After histopathological assessment and confirmation, intravenous blood samples were collected from the two groups of patients in sterile plastic disposable syringes. The blood samples were then transferred in to glass bottles containing 3.8\% sodium citrate. Single cell electrophoresis was carried out for both these groups and the DNA damage was quantified using a fluorescence microscope following the method outlined by Rao et $\mathrm{al}^{19}$ and Singh et al. ${ }^{20}$

\section{Preparation of the Reagents}

The following reagents were prepared as per the protocol for using the single cell electrophoresis. All the necessary materials for preparation of the reagents were obtained from Sigma Chemical Company (St Louis, MO, USA).

Dulbecco's phosphate buffered saline ( $\mathrm{Ca}$ and $\mathrm{Mg}$ free): Sodium chloride $(8 \mathrm{gm})$, potassium chloride $(0.2 \mathrm{gm})$, disodium hydrogen orthophosphate (1.15 gm) and potassium dihydrogen phosphate $(0.2 \mathrm{gm})$ were dissolved in $500 \mathrm{ml}$ of distilled water at $7.4 \mathrm{pH}$ and stored at $4^{\circ} \mathrm{C}$.

Lysing solution: Sodium chloride (146.4 gm), Ethylene Diamine Tetra Acetic acid (EDTA; $37.2 \mathrm{gm}$ ) and Tris buffer (1.2 gm) were each dissolved in $1000 \mathrm{ml}$ of distilled water to formulate a $2.5 \mathrm{H}$ sodium chloride solution, $100 \mathrm{~mm}$ EDTA and $10 \mathrm{~mm}$ Tris solution respectively. Sodium hydroxide was then added and $\mathrm{pH}$ was set at 10 . The final lysing solution was prepared with $36 \mathrm{ml}$ of the above prepared solution with 1\% Triton X-100 (0.4 ml) and dimethyl sulfoxide $(4 \mathrm{ml})$, which was stored in amber colored bottles at $4^{\circ} \mathrm{C}$.

Electrophoresis buffer: The stock solutions of $10 \mathrm{~N}$ sodium hydroxide and $200 \mathrm{~mm}$ EDTA was prepared by dissolving $50 \mathrm{gm}$ of sodium hydroxide in $500 \mathrm{ml}$ of distilled water and EDTA (7.4 gm) along with 1.2 gm sodium hydroxide in $100 \mathrm{ml}$ distilled water respectively. Before each run, fresh buffer was prepared with $30 \mathrm{ml}$ sodium hydroxide and $5 \mathrm{ml}$ EDTA taken from the above stock solutions and made up to $1000 \mathrm{ml}$ at a concentration of $300 \mathrm{~mm}$ sodium hydroxide and $1 \mathrm{~mm}$ EDTA respectively.

Neutralization buffer: Tris (48.5 gm) was dissolved in $1000 \mathrm{ml}$ of distilled water to prepare $0.4 \mathrm{M}$ tris buffer solution which was then set at a $\mathrm{pH}$ of 7.5 with concentrated hydrochloric acid and stored at room temperature until further use.

Staining solution: A stock staining solution of ethidium bromide was prepared by dissolving $10 \mathrm{mg}$ of it in $50 \mathrm{ml}$ distilled water. For the working solution, $1 \mathrm{ml}$ of the above prepared solution was mixed with $9 \mathrm{ml}$ of distilled water. 


\section{Preparation of the Slides}

Slide preparation was performed under dim yellow light to prevent additional DNA damage. A total of $0.5 \%$ of low melting and regular agarose was prepared with agar $(125 \mathrm{mg})$ and phosphate-buffered saline (PBS) $(25 \mathrm{ml})$. Approximately $5 \mathrm{ml}$ of the cell suspension was mixed with low melting agarose $(70 \mathrm{ml})$ and placed over the frozen regular agarose on the slide with coverslips. After adequate solidification of the agarose, the coverslip was removed and the slide was slowly lowered into cold lysing solution and placed in a refrigerator overnight.

\section{Electrophoresis of the Slides}

The slides were removed from the lysing solution and placed in a horizontal gel electrophoresis system near the anode end, sliding them as closely together as possible. The buffer reservoir was filled with freshly made electrophoresis buffer solution until the liquid level completely covered the slides without any bubbles over the agarose. The slides were immersed in the alkaline buffer for 20 minutes to allow unwinding of the DNA. The power supply was adjusted to $25 \mathrm{~V}$ and $600 \mathrm{~mA}$ by slowly raising and lowering the buffer level.

\section{Staining Procedure}

The slides were removed from the buffer and placed on a staining tray. The slides were coated drop wise with neutralization buffer and left for 10 minutes. The procedure was repeated twice. Following which, the slides were drained and $50 \mathrm{ml}$ of the prepared working solution of ethidium bromide was added and then covered with a fresh coverslip. The excess liquid was blotted with a tissue paper and the coverslips were sealed with vaseline.

\section{Evaluation of DNA Damage}

The ethidium bromide stained slides were examined for DNA damage using a fluorescent microscope (Olympus $B \times 53$, Tokyo, Japan) at $250 \times$ magnification. The images were captured and the measurement of the tail length is done using Image J (National Institute of Health, MD, USA) software. A randomly selected 25 cells per slide were analyzed. The data was tabulated and analyzed using GraphPad $^{\circledR}$ Instat 3.05 software (GraphPad Software Inc, San Diego, CA, USA). The significance between the groups were assessed by ANOVA with post hoc test. A $\mathrm{p}$-value $\leq 0.05$ was taken as statistically significant.

\section{RESULTS}

Deoxyribonucleic acid damage levels in OL $(n=30)$ patients and normal $(\mathrm{n}=10)$ individuals were assessed using SCGE assay. The level of damage was expressed as the length of tail measured in $\mu \mathrm{m}$. The mean tail length of leukoplakia patient with moderate to severe dysplasia was $1.25 \pm 0.14 \mu \mathrm{m}$ while for control it was $0.31 \pm 0.10 \mu \mathrm{m}$ (Table 1). The difference was statistically significant $(p=0.000)$. Results showed a significant increase in DNA damage in patients with moderate to severe dysplasia, and a statistical significance of $p<0.001$ was found when compared with normal subjects.

The different grades of epithelial dysplasia showed variations in the levels of DNA damage (Table 1, Graph 1). Also the DNA damage levels in leukoplakia patients with histologically nondysplastic epithelium when compared with control group $(0.47 \mu \mathrm{m}$ and $0.31 \mu \mathrm{m}$ respectively) showed statistically significant differences $(\mathrm{p}<0.01)$. DNA damage values in patients whose epithelium showed mild to severe dysplasia (Fig. 1) when compared with those showing nondysplastic epithelium and controls also showed statistically significant difference $(p<0.001)$.

Table 1: The mean DNA damage in different histologic groups of leukoplakia patients

\begin{tabular}{lllll}
\hline & $\begin{array}{l}\text { Control } \\
\text { Sl. no. }\end{array}$ & $\begin{array}{l}\text { Nondysplastic } \\
(n=10)\end{array}$ & $\begin{array}{l}\text { Mild } \\
\text { dysplasia } \\
(n=10)\end{array}$ & $\begin{array}{l}\text { Moderate to } \\
\text { severe dysplasia } \\
(n=10)\end{array}$ \\
\hline 1 & 0.31 & 0.48 & 0.57 & 0.95 \\
2 & 0.32 & 0.49 & 0.62 & 1.24 \\
3 & 0.32 & 0.42 & 0.66 & 1.34 \\
4 & 0.33 & 0.39 & 0.59 & 1.13 \\
5 & 0.31 & 0.45 & 0.62 & 1.21 \\
6 & 0.51 & 0.38 & 0.64 & 1.22 \\
7 & 0.22 & 0.45 & 0.58 & 1.45 \\
8 & 0.38 & 0.62 & 0.52 & 1.34 \\
9 & 0.12 & 0.46 & 0.79 & 1.33 \\
10 & 0.32 & 0.54 & 0.62 & 1.25 \\
Mean & 0.31 & 0.47 & 0.62 & 1.25 \\
SD & 0.10 & 0.07 & 0.07 & 0.14 \\
\hline
\end{tabular}

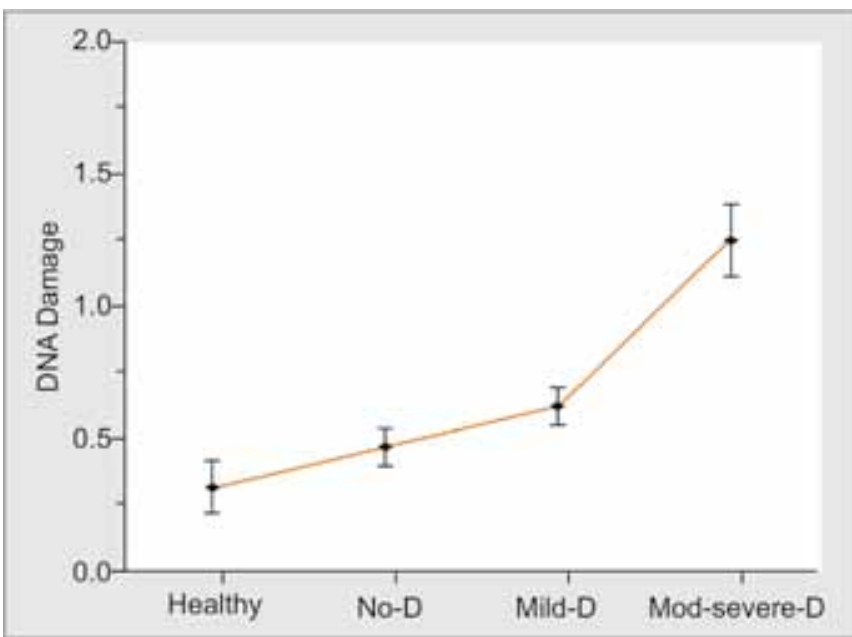

Graph 1: Comparison of DNA damage in different histologic groups of leukoplakia patients 


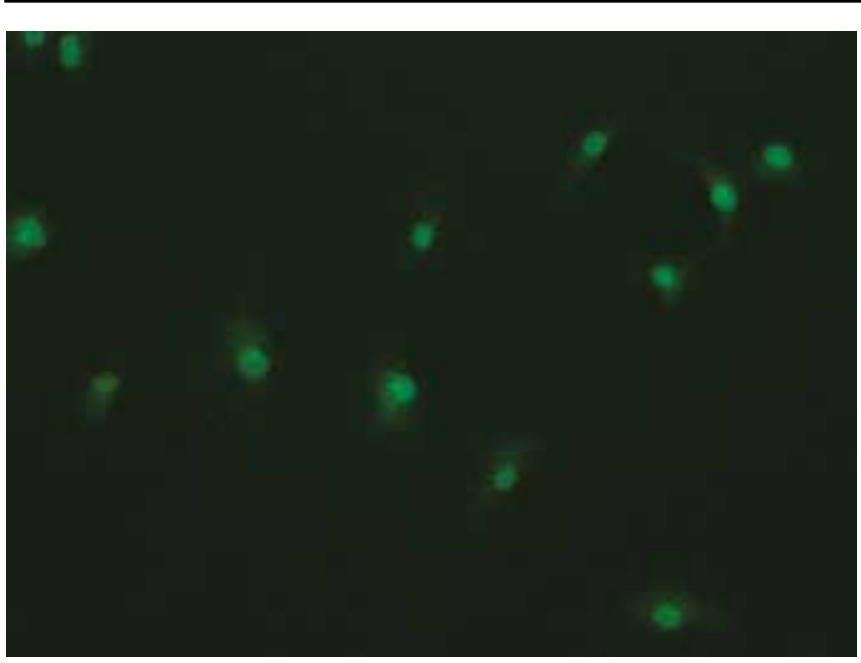

Fig. 1: The SCGE (comet) assay showing DNA fragmentation in $\mathrm{OL}$

\section{DISCUSSION}

Several epidemiological and clinical studies have demonstrated an independent, clear cut association of deleterious paranormal oral habits, such as smoking tobacco, betel quid chewing and chewing tobacco with occurrence of oral cancer. ${ }^{21}$ The precancerous condition of leukoplakia is characterized by a white patch, mainly associated with tobacco smokers, the prevalence of which is considered high in a developing country like India. This condition has high cancer turnover potentiality and if detected early can be prevented and treated successfully. ${ }^{11}$ With rapid advances in genotoxicologic studies and better assessment of the extent of DNA damage, the knowledge gained from these resources may provide a platform to determine the cancer progression. ${ }^{22}$

The association of the deleterious oral habits with DNA damage has been clearly established in a previous study. ${ }^{11}$ Comet assay provides a generalized picture of a particular population that reflects whether it is an associated environmental carcinogenic stress, and may in turn become an epidemiologic asset. The results of the present study indicate that DNA damage in the study population is associated with leukoplakia. Tobacco smoking and pan chewing or presence of any deleterious oral habit may lead to DNA with greater tail length. The results are consistent with earlier reports in literature. ${ }^{11}$ Oral squamous cell carcinoma (OSCC) is often preceded by several changes in the overlying epithelium, which are observed histopathologically as dysplastic changes. ${ }^{23}$ It is important to quantify these dysplastic changes in oral epithelium as the degree of dysplasia is limited to the degree of probability to the development of malignancy. ${ }^{24}$

Damage to DNA is suggested to be a common mechanism for cancer initiation. Deoxyribonucleic acid damage especially that which is radiation induced has been assessed by comet assay, ${ }^{20}$ but the use of this technique in cancer has been limited. Using comet assay, it was shown that patients with cervical carcinoma exhibited increased DNA damage in peripheral blood leukocytes (PBL) when compared to normal individuals. ${ }^{25}$ Using the same technique, the PBL of patients with OSCC, showed a significant increase in DNA damage, depending on the clinical staging and histopathological grading. ${ }^{19}$ The DNA damage levels in PBL in patients with precancerous lesions of the cervix, showed a significant stepwise increase in the mean DNA damage in the leukocytes, from normal or control groups to patients with different grades of dysplasia. ${ }^{25}$

A stepwise increase in DNA damage in leukoplakia patients, from nondysplastic epithelium to increasing grades of dysplasia and statistically significant differences in DNA damage degree levels, between mild dysplasia and the nondysplastic epithelium and healthy controls, suggest the usefulness of this technique in assessing the dysplastic grades in OL patients and its sensitivity in detecting changes, much before morphological features of dysplasia become evident under the light microscope.

Smoking is regarded as the most important etiologic factor in the development of OL. Using the comet assay, increased DNA damage in exfoliated buccal cells of smokers, has been observed. ${ }^{26}$ All the leukoplakia patients in this study were users of tobacco and therefore it can be expected that the altered oral epithelial cells to show DNA damage. It may be speculated that probably the PBL of these patients reflect the DNA damage of the epithelial cells. Similar reports have emanated from North Eastern India. ${ }^{11}$ In various studies, the systemic host response plays a major role in determining the findings in peripheral blood in malignancy. ${ }^{19,25,27,28}$ As premalignant changes recognized as epithelial dysplasias and regarded as a fore runner of malignancy, a systemic host response in premalignant lesion is suggested, on the basis of the findings from this study.

Oral squamous cell carcinoma is often preceded by several biochemical and clinical changes in the overlying epithelium. Such histological changes are often observed and referred as dysplastic changes in the oral epithelium. ${ }^{23}$ Careful study and analysis of the same may be useful to predict the chances of malignant transformation. ${ }^{24}$ The stage at which oral cancer is diagnosed plays an important role in determining the mortality and morbidity following treatment. ${ }^{29}$ For instance, for the early stage of the disease (Stage 1), there is an estimated $80 \% 5$-year survival rate whereas for the advanced stage of the disease (Stage 4), the 5 years survival rate can be as low as $20 \% .^{30} \mathrm{~A}$ pilot study using comet assay was done on OSCC patients. ${ }^{19}$ This study reported increased DNA damage in peripheral blood cells of OSCC patients. 
However, the effect of tobacco smoke on oral exfoliated basal cells has been found to cause single-strand breaks (SSBs) in DNA. ${ }^{26}$ Similar reports has also been reported from precancerous and cancerous lesions of the cervix where a stepwise increase in DNA damage was observed in dysplastic cervical epithelial cells. ${ }^{25}$

The limitation of the study is that small sample size as well as the history of smoking among subjects. However all subjects in the study groups were smokers. Despite the above limitations, present study has been able to demonstrate that DNA damage in blood cells measured by SCGE is greater in leukoplakia than controls and establishes that deleterious oral habits are associated with such greater DNA damage. Further studies with larger samples and correlation of comet assay findings with other markers might help to calibrate this simple assay as a prognostic indicator in leukoplakia patients.

\section{CONCLUSION}

The results of this study confirm the increased damage to DNA with increasing grades of epithelial dysplasia. It is evident that peripheral blood and SCGE could be important non-invasive biomarkers for diagnosis and monitoring prognosis of the lesions. The study also identifies potential situations where demonstrating DNA damage using SCGE may lead to further advancement in our understanding of the biology of oral cancer and pre-cancer for developing possible worthy early detection tests for oral cancer.

\section{REFERENCES}

1. Silverman S Jr, Gorsky M, Lozada F. Oral leukoplakia and malignant transformation. A follow-up study of 257 patients. Cancer 1984;53(3):563-568.

2. Baric JM, Alman JE, Feldman RS, Chauncey HH. Influence of cigarette, pipe, and cigar smoking, removable partial dentures, and age on oral leukoplakia. Oral Surg Oral Med Oral Pathol 1982;54(4):424-429.

3. Warnakulasuriya S, Dietrich T, Bornstein MM, Casals Peidro E, Preshaw PM, Walter C, Wennstrom JL, Bergstrom J. Oral health risks of tobacco use and effects of cessation. Int Dent J 2010;60(1):7-30.

4. Maserejian NN, Joshipura KJ, Rosner BA, Giovannucci E, Zavras AI. Prospective study of alcohol consumption and risk of oral premalignant lesions in men. Cancer Epidemiol Biomarkers Prev 2006;15(4):774-781.

5. Syrjanen S, Lodi G, von Bultzingslowen I, Aliko A, Arduino P, Campisi G, Challacombe S, Ficarra G, Flaitz C, Zhou HM, et al. Human papillomaviruses in oral carcinoma and oral potentially malignant disorders: a systematic review. Oral Dis 2011;17 Suppl 1:58-72.

6. Lumerman H, Freedman P, Kerpel S. Oral epithelial dysplasia and the development of invasive squamous cell carcinoma. Oral Surg Oral Med Oral Pathol Oral Radiol Endod 1995;79(3): 321-329.
7. Dietrich T, Reichart PA, Scheifele C. Clinical risk factors of oral leukoplakia in a representative sample of the US population. Oral Oncol 2004;40(2):158-163.

8. Brouns ER, Bloemena E, Belien JA, Broeckaert MA, Aartman IH, van der Waal I. DNA ploidy measurement in oral leukoplakia: different results between flow and image cytometry. Oral Oncol 2012;48(7):636-640.

9. Gupta PC, Mehta FS, Daftary DK, Pindborg JJ, Bhonsle RB, Jalnawalla PN, Sinor PN, Pitkar VK, Murti PR, Irani RR, et al. Incidence rates of oral cancer and natural history of oral precancerous lesions in a 10-year follow-up study of Indian villagers. Community Dent Oral Epidemiol 1980;8(6): 283-333.

10. Pindborg JJ, Jolst O, Renstrup G, Roed-Petersen B. Studies in oral leukoplakia: a preliminary report on the period pervalence of malignant transformation in leukoplakia based on a follow-up study of 248 patients. J Am Dent Assoc 1968;76(4):767-771.

11. Mukherjee S, Ray JG, Chaudhuri K. Evaluation of DNA damage in oral precancerous and squamous cell carcinoma patients by single cell gel electrophoresis. Indian J Dent Res 2011;22(5):735-736.

12. Zhang L, Rosin MP. Loss of heterozygosity: a potential tool in management of oral premalignant lesions? J Oral Pathol Med 2001;30(9):513-520.

13. Abbey LM, Kaugars GE, Gunsolley JC, Burns JC, Page DG, Svirsky JA, Eisenberg E, Krutchkoff DJ, Cushing M. Intraexaminer and interexaminer reliability in the diagnosis of oral epithelial dysplasia. Oral Surg Oral Med Oral Pathol Oral Radiol Endod 1995;80(2):188-191.

14. Pindborg JJ, Reibel J, Holmstrup P. Subjectivity in evaluating oral epithelial dysplasia, carcinoma in situ and initial carcinoma. J Oral Pathol 1985;14(9):698-708.

15. van der Waal I. Potentially malignant disorders of the oral and oropharyngeal mucosa; present concepts of management. Oral Oncol 2010;46(6):423-425.

16. Chang KP, Chang YT, Liao CT, Yen TC, Chen IH, Chang YL, Liu YL, Chang YS, Yu JS, Wu CC. Prognostic cytokine markers in peripheral blood for oral cavity squamous cell carcinoma identified by multiplexed immunobead-based profiling. Clin Chim Acta 2011;412(11-12):980-987.

17. Bijian K, Mlynarek AM, Balys RL, JieS, Xu Y,Hier MP, Black MJ, Di Falco MR, LaBoissiere S, Alaoui-Jamali MA. Serum proteomic approach for the identification of serum biomarkers contributed by oral squamous cell carcinoma and host tissue microenvironmentt. J Proteome Res 2009;8(5):2173-2185.

18. Kramer IR, Lucas RB, Pindborg JJ, Sobin LH. Definition of leukoplakia and related lesions: an aid to studies on oral precancer. Oral Surg Oral Med Oral Pathol 1978;46(4):518-539.

19. Rao GV, Kumar GS, Ahuja YR. Single cell gel electrophoresis on peripheral blood leukocytes of patients with oral squamous cell carcinoma. J Oral Pathol Med 1997;26(8):377-380.

20. Singh NP, McCoy MT, Tice RR, Schneider EL. A simple technique for quantitation of low levels of DNA damage in individual cells. Exp Cell Res 1988;175(1):184-191.

21. Warnakulasuriya S. Significant oral cancer risk associated with low socioeconomic status. Evid Based Dent 2009;10(1):4-5.

22. Ribeiro DA. The single cell gel (comet) assay as a promising tool for the detection of DNA damage induced by compounds used in dental practice: the oral cancer risk assessment. Crit Rev Oncog 2008;14(2):165. 
23. Langdon JD. Oral cancer: raising the level of awareness. Dent Update 1995;22(7):269-270.

24. Burkhardt A. Advanced methods in the evaluation of premalignant lesions and carcinomas of the oral mucosa. J Oral Pathol 1985;14(10):751-778.

25. Jaiswal M, Anuradha G, Rajeswari N, Raju K, Balakrishna N, Visweswara Rao K, Satva Prasad I, Jain S, Ahuja Y. Comet assay on cervical epithelial cells and leucocytes of patients with precancerous and cancerous lesions of the cervix. Med Sci Res 1994;22(12):879-882.

26. Rojas E, Valverde $M$, Sordo M, Ostrosky-Wegman P. DNA damage in exfoliated buccal cells of smokers assessed by the single cell gel electrophoresis assay. Mutat Res 1996;370(2): 115-120.

27. Nieburgs HE, Goldberg AF. Changes in polymorphonuclear leukocytes as a manifestation of malignant neoplasia. Cancer 1968;22(1):35-42.

28. Chomet B, LaPorte J, McGrew EA. Atypical monocytes in patients with malignant tumors. Acta Cytol 1966;10(3):197-199.

29. Murphy BA, Gilbert J, Cmelak A, Ridner SH. Symptom control issues and supportive care of patients with head and neck cancers. Clin Adv Hematol Oncol 2007;5(10):807-822.

30. McGurk M, Chan C, Jones J, O'Regan E, Sherriff M. Delay in diagnosis and its effect on outcome in head and neck cancer. Br J Oral Maxillofac Surg 2005;43(4):281-284. 